\title{
Endoscopic management of benign recalcitrant esophageal strictures
}

\author{
Umesha Boregowda ${ }^{a}$, Hemant Goyal ${ }^{b}$, Rupinder Mannc, Mahesh Gajendrand, Sandeep Patele, \\ Juan Echavarriae, Hari Sayana', Shreyas Saligrame
}

Bassett Medical Center, Cooperstown, NY; The Wright Center for Graduation Medical Center, Scranton, PA; Saint Agnes Medical Center, Fresno, CA; Texas Tech University Health Sciences Center, El Paso, TX; University of Texas Health, San Antonio, TX, USA

\section{Abstract}

\begin{abstract}
Benign esophageal strictures are one of the common clinical conditions managed by endoscopists. Nearly $90 \%$ of the benign esophageal strictures respond to endoscopic dilation. However, a small percentage of patients progress to recalcitrant strictures. The benign recalcitrant esophageal strictures are difficult to manage both medically and endoscopically as they do not respond to conventional treatment with proton pump inhibitors and esophageal dilations. Patients with benign recalcitrant esophageal strictures are at a high risk of developing debilitating malnutrition and morbidity due to severe dysphagia. This condition is associated with psychological trauma to patients as treatments are usually prolonged with poor outcomes. Also, this can be a financial burden on the healthcare industry due to several sessions of treatment. In this article, we discuss the classification of benign esophageal strictures, evidence-based treatment strategies, endoscopic procedural techniques, and complications of endoscopic interventions. We aim to guide providers in managing benign esophageal strictures with a focus on endoscopic management of benign recalcitrant esophageal strictures.
\end{abstract}

Keywords Benign recalcitrant esophageal strictures, intralesional steroid injection, mitomycin C, IT knife, esophageal stent

Ann Gastroenterol 2021; 34 (1): 1-13

\section{Introduction}

Esophageal strictures are anatomical lesions that can cause luminal narrowing of the esophagus. These are usually diagnosed on upper endoscopy or esophagogram either as an incidental finding or during the workup of dysphagia. Peptic strictures are the most common cause of benign esophageal strictures [1].

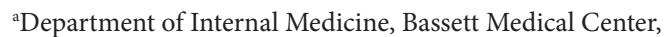
Cooperstown, NY (Umesha Boregowda); ${ }^{b}$ Department of Medicine, The Wright Center for Graduation Medical Center, Scranton, PA (Hemant Goyal); 'Department of Internal Medicine, Saint Agnes Medical Center, Fresno, CA (Rupinder Mann); ${ }^{\mathrm{d} D e p a r t m e n t ~ o f ~ I n t e r n a l ~}$ Medicine, Texas Tech University Health Sciences Center, El Paso, TX

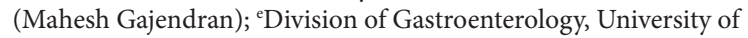
Texas Health, San Antonio, TX (Sandeep Patel, Juan Echavarria, Hari Sayana, Shreyas Saligram), USA

Conflict of Interest: None

Correspondence to: Hemant Goyal MD FACP PGDCA (MBA), The Wright Center for Graduate Medical Education, 501 S. Washington St, Scranton, PA 18505, USA, e-mail: doc.hemant@yahoo.com

Received 13 August 2020; accepted 2 November 2020; published online 27 January 2021

DOI: https://doi.org/10.20524/aog.2021.0585
However, their incidence has decreased with the widespread use of proton pump inhibitors (PPI). Eosinophilic esophagitis is increasingly being recognized as a common benign cause of dysphagia [2]. Other common causes of esophageal strictures are anastomotic strictures, radiation, and Schatzki ring (B-ring). Less commonly, congenital (e.g., muscular rings), caustic ingestion, medications, and other autoimmune diseases can also be associated with esophageal strictures [3,4]. Table 1 lists the causes of benign recalcitrant esophageal strictures. The most common symptom associated with esophageal strictures is dysphagia to solids $[5,6]$. Other symptoms are odynophagia, food impaction, and heartburn [7]. Patients with caustic injury may also present with hematemesis, hoarseness, and stridor [8]. However, atypical symptoms such as chest pain and coughing due to aspiration can also develop. Because of persistent dysphagia or odynophagia, some patients can also present with nutritional deficiencies and weight loss $[9,10]$. In clinical practice, caustic strictures, iatrogenic strictures such as anastomotic strictures post-IvorLewis esophagectomy, post-endoscopic submucosal dissection (ESD), post-radiation strictures, and post-esophageal banding strictures are the most challenging to treat. In particular, caustic injuries involve long segments and affect the deeper tissue of the esophagus. These strictures can be angulated and may not allow the standard endoscope to pass through [11]. 
In this review, we discuss the classification of benign esophageal strictures, the available endoscopic treatment options and techniques of endoscopic interventions with their potential complications, and the future directions in the management of benign recalcitrant esophageal strictures.

\section{Classification}

Benign esophageal strictures are classified into simple and complex strictures $[12,13]$.

\section{Simple strictures}

An esophageal stricture is considered as simple if it is focal, short ( $<2 \mathrm{~cm}$ in length), and a lumen diameter of $>12 \mathrm{~mm}$. An adult endoscope which has a diameter of $10 \mathrm{~mm}$ can traverse simple strictures with ease, and they are amenable to endoscopic dilation [2]. On average, simple strictures require 1-3 dilations to relieve symptoms of dysphagia [12]. The most common causes of simple strictures are peptic strictures, Schatzki ring, esophageal web, and eosinophilic esophagitis [13].

\section{Complex strictures}

Complex esophageal strictures are usually longer than $2 \mathrm{~cm}$, irregular, tortuous, or angulated with a severely narrowed lumen. The luminal diameter is $<12 \mathrm{~mm}$ [2]. They might not allow a standard size endoscope to traverse the stricture [14]. Complex strictures are difficult to manage due to a more frequent recurrence compared to simple strictures. Common causes of complex strictures are corrosive injury, anastomotic strictures, radiation-induced strictures, and strictures due to the complication from ESD [13].

Both simple and complex strictures can progress to benign recalcitrant esophageal strictures despite their treatment.

Table 1 Common causes of benign recalcitrant esophageal strictures

Common causes of benign recalcitrant esophageal strictures

\begin{tabular}{l}
\hline Peptic strictures \\
Schatzki ring \\
Radiation therapy \\
Post-anastomotic strictures \\
Eosinophilic esophagitis \\
Sclerotherapy \\
Caustic injury \\
Photodynamic therapy
\end{tabular}

Iatrogenic (e.g., post-endoscopic mucosal resection, post-endoscopic submucosal, post-esophageal varices ligation and sclerosis)
The benign recalcitrant esophageal strictures can be further classified as shown below.

\section{Benign refractory esophageal strictures}

Failure to achieve an esophageal luminal diameter of $>14 \mathrm{~mm}$ after 5 sessions of endoscopic dilation with 2-week intervals are considered refractory strictures [2]. This is mainly due to underlying fibrosis, and visible inflammation is absent by endoscopy. Fig. 1 illustrates an example of recalcitrant benign esophageal stricture.

\section{Benign recurrent esophageal strictures}

Inability to maintain a luminal diameter of $>14 \mathrm{~mm}$ for more than 4 weeks after achieving initial dilation to $>14 \mathrm{~mm}$ is considered as a recurrent benign esophageal stricture [15]. This is also due to underlying fibrosis, and there is no visible inflammation on endoscopy.

\section{Predictors of recurrence}

Recurrent symptoms of dysphagia despite dilation can be as high as $40 \%[2,16]$. This means that recurrence rates of strictures are high despite dilation and medical management. Prior literature suggests that the persistence of heartburn after dilation despite the use of PPI predicts recurrence among peptic strictures [17]. In a case-control study, 87 consecutive patients with benign esophageal strictures undergoing initial dilation were followed for 1 year. Multivariate analysis at the end of the study showed that non-peptic strictures and a narrower diameter of the stricture predicted recurrence. Uncontrolled acid reflux, non-peptic strictures such as anastomotic strictures, strictures due to surgery, corrosive injury, undiagnosed eosinophilic esophagitis, and radiation

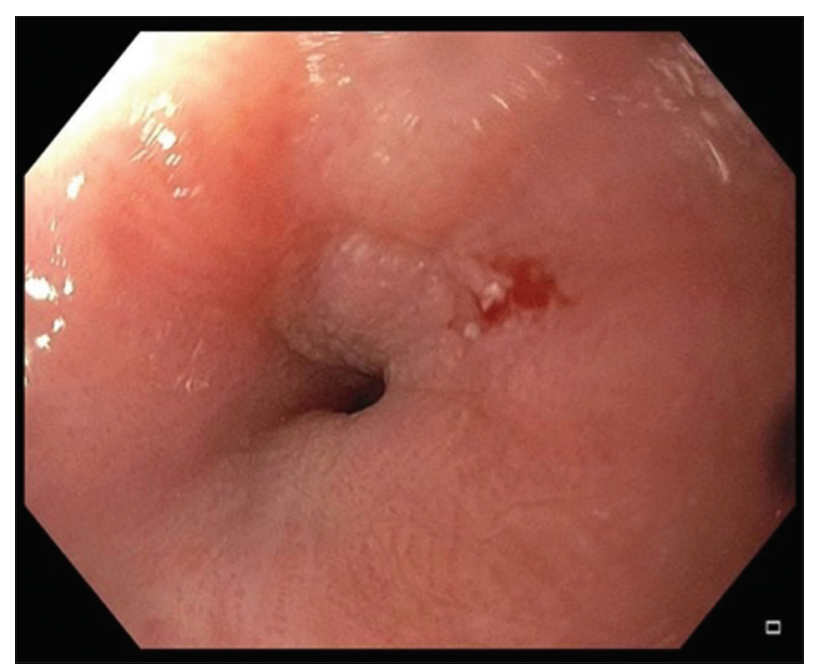

Figure 1 Benign recalcitrant esophageal stricture 
(33\%) [14] have a higher tendency for recurrence compared to peptic strictures. Severe esophageal stenosis (luminal diameter $<9 \mathrm{~mm}$ ), use of fluoroscopy during dilation, and female sex also predicted the risk of recurrence in radiation strictures $[14,17]$.

\section{Treatment strategies}

\section{Medical management of benign esophageal strictures}

Reflux esophagitis due to gastric acid causes collagen and fibrous tissue deposition leading to stricture formation [18]. Persistent acid exposure to the esophagus will result in fibrosis, which in turn can lead to a benign recalcitrant esophageal stricture. Therefore, protection from injury due to acid reflux can play a role in the healing of reflux esophagitis and strictures. Although there is no direct evidence, the literature suggests that the increasing use of PPI from the year 1994 to 2000 has led to a decreased incidence of esophageal strictures, indirectly suggesting that PPI can play a significant role in the treatment of benign esophageal strictures. The incidence of benign esophageal strictures was 1.1 per 10,000 before PPI use, which decreased to 0.6 (95\% confidence interval [CI] 0.3-1.1) later [19].

Protection of the esophageal mucosa from acid reflux can be achieved through gastric acid suppression and also by providing a mechanical barrier. Commonly used acid-suppressing agents are PPI and histamine-2 receptor antagonists (H2RA) (e.g., famotidine). Literature suggests PPIs are superior to H2RA in gastric acid suppression. A randomized controlled trial (RCT) $(n=366)$ showed that patients who received omeprazole after endoscopic dilation needed fewer re-dilations compared to those who received ranitidine ( $30 \%$ vs. $46 \%$; $\mathrm{P}<0.01$ ) [20]. Sucralfate can provide a mechanical barrier by coating the esophageal mucosa at the site of injury, preventing further injury. A prospective study involving 15 patients with corrosive injury evaluated the effectiveness of sucralfate for the prevention of recurrent strictures and consequently the reduction in the need for repeat dilations. At the end of 3 and 6 months, patients who received intense sucralfate therapy had a significantly lower recurrence of a stricture compared to those who did not ( 1 of 8 vs. 6 of $7 ; \mathrm{P}<0.01$ ) [21].

In our practice, all patients who undergo endoscopic dilation receive a high-dose PPI (e.g., omeprazole $40 \mathrm{mg}$ b.i.d.) along with sucralfate to help the healing of the esophageal ulcer and reduce acid injury during the course of dilation of benign simple or complex esophageal strictures thereby minimizing or preventing benign recalcitrant esophageal strictures.

\section{Endoscopic management of benign esophageal strictures}

Nearly $80-90 \%$ of the benign esophageal strictures can be treated with $\leq 5$ sessions of balloon dilation [22,23].

\section{Endoscopic dilation}

Esophageal dilation is the first step in the treatment of symptomatic benign esophageal strictures. Dilation can be done using endoscopic balloon dilators or Savary-Gilliard ${ }^{\oplus}$ (SG) dilator (Cook Medical, USA). SG dilator produces longitudinal shear force and a radial force together; on the other hand, balloon dilators produce only radial force [24]. The SG dilator may dilate "non-visible" stenoses along the entire length of the esophagus, especially with the small-caliber esophagus, as they are frequently seen in cases of eosinophilic esophagitis [25]. The size of the SG dilator is fixed and known. Therefore, bougie dilation can also provide a good estimate of the luminal diameter at the stricture once the procedure is completed. The balloon dilator has the advantage of direct visualization of the stricture and the ability to control the radial force applied during the dilation. Visualization of the stenosis through the balloon gives the theoretical advantage of visualizing a significant tear early on, therefore allowing to deflate the balloon early on to potentially avoid a perforation. Both SG and balloon dilators are equally effective and safe in achieving adequate dilation [26]. The absolute contraindication for dilation is the presence of acute or incompletely healed esophageal perforation. Documented relative contraindications are uncontrolled coagulopathy or the use of anticoagulants and the inability to safely sedate patients due to cardiopulmonary or anatomic abnormalities [27]. Fig. 2 shows before and after pictures of a benign recalcitrant esophageal stricture treated with balloon dilation.

\section{Techniques and complications of endoscopic balloon dilation}

Visualization of the stricture and selection of appropriate scope size is important to achieve better results. Prior knowledge about the duration, length, and luminal size of the stricture and its etiology can assist in making these decisions. It is recommended to use a balloon size 1-2 mm larger than the size of the stricture and to limit the target dilation to no more than 3 dilators of sequential size once moderate or greater resistance is noted ("rule of 3"). However, such "rules" are only based on an expert's opinion [28]. Recent studies have shown that not adhering to the "rule of 3" did not increase the risk of perforation or other adverse events in the benign esophageal strictures [29,30]. It is our institution's experience that more aggressive and longer treatments may lead to the best long-term results, although they may not be cost-effective. There is no difference in clinical outcomes between wire-guided bougie and through-the-scope balloon dilators. The optimal duration of balloon inflation is not known. However, inflation for 30-60 sec is recommended [12,31]. A pressure gauge helps monitor the pressure during insufflation [31]. The balloon is deflated before repeating the dilation. Endoscopic inspection is recommended after each balloon size insufflation to look at the stricture site for signs of mucosal tear. If there is minimal or no dilatation, the balloon can be insufflated to the next size. Endoscopists should also continue to communicate with the endoscopy assistant 


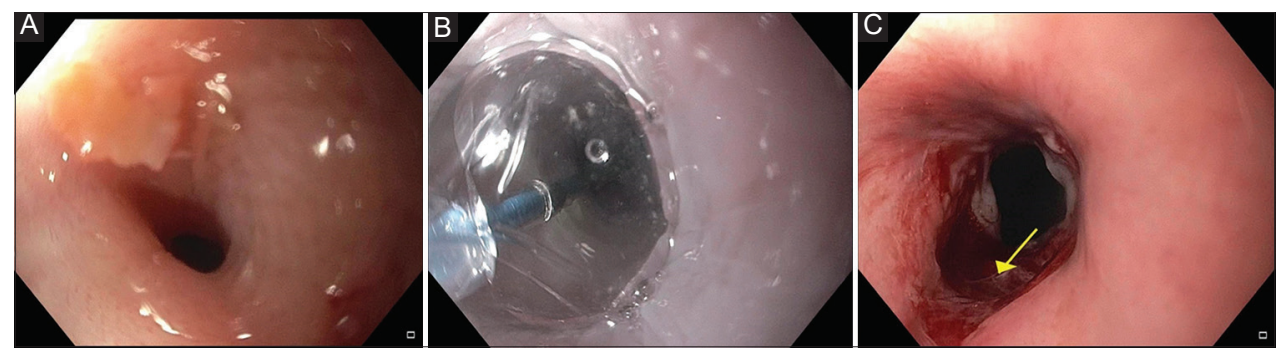

Figure 2 Balloon dilation of a benign recalcitrant esophageal stricture (A) Pre-dilation, (B) Balloon dilation, and (C) Post-dilation mucosal tear

insufflating the balloon for the development of resistance, which could give a fair idea of radial force on the esophageal wall. If a significant esophageal mucosal tear is noted, no further dilation should be attempted. When the lumen is dilated to $>16 \mathrm{~mm}$, anastomotic strictures usually have longer symptom-free interval and can prolong the intervals between the dilations [30]. Most patients can tolerate a normal diet when the luminal diameter is $13-15 \mathrm{~mm}[27,32]$. Practice guidelines from the United Kingdom recommend dilation of luminal size to $>15 \mathrm{~mm}$ for sustained symptomatic improvement [10].

\section{Techniques and complications of SG dilation}

SG dilation includes passage of a SG dilator of a particular diameter based on the prior knowledge of stricture length and luminal size. SG dilators are available in varying sizes from 18-60 Fr (6-20 mm). SG dilators have a guidewire over which the dilator is inserted. The endoscopist passes these dilators and relies on the tactile perception to determine the effectiveness and need for repetition. Typically, multiple passes are needed to achieve the required dilation. Intermittent re-inspection is similarly helpful when SG dilator is being used to look at the stricture site for signs of mucosal tear. The most common complications due to SG dilation are hemorrhage, perforation, and are more common with the blind passage of the non-guidewire dilators [22].

\section{Endoscopic dilation with the aid of fluoroscopy}

If the adult esophagogastroduodenoscopy (EGD) scope or pediatric EGD scope can traverse the stricture to insert a guidewire, dilation can be performed without the aid of fluoroscopy. However, in complex strictures, it may not always be possible to traverse the stricture with the endoscope to pass the guidewire. Contrast dye has to be injected to delineate the length and diameter of the stricture. A guidewire has to be passed carefully across the stricture, and either a balloon dilator or SG dilator can be passed over the guidewire with the aid of fluoroscopy to dilate it to the desired size.

\section{SG vs. endoscopic balloon dilation}

Previous studies have shown that both balloon and SG dilations are comparable in relieving dysphagia symptoms, recurrence, and complications. A meta-analysis of 5 RCTs comparing SG vs. balloon dilation of benign esophageal strictures showed no significant difference in symptomatic relief (risk difference $0.00,95 \% \mathrm{CI}-0.08$ to $0.08 ; \mathrm{P}=0.92$ ), rate of recurrence (risk difference $0.03,95 \% \mathrm{CI}-0.05$ to $0.10 ; \mathrm{P}=0.46$ ), bleeding (risk difference $-0.02,95 \% \mathrm{CI}-0.06$ to $0.02 ; \mathrm{P}=0.38$ ), or perforation (risk difference $-0.01,95 \% \mathrm{CI}-0.03$ to 0.02 ; $\mathrm{P}=0.66$ ). However, patients who underwent balloon dilation had a significantly lower post-procedure pain incidence compared to SG dilation (risk difference $-0.5,95 \% \mathrm{CI}-0.47$ to -0.07; $\mathrm{P}=0.007$ ) [33].

\section{Endoscopic management of benign recalcitrant esophageal strictures}

Benign recalcitrant stricture remediation can be complex and risky. There are various advanced endoscopic techniques available to treat these strictures. Our approach is to treat these strictures with low-risk minimally invasive procedures and then advance to high-risk minimally invasive procedures in nonresponsive patients. The goal of treatment is to relieve dysphagia symptoms from mechanical stenosis and prevent recurrence of stricture, thereby providing a durable effect [27].

Endoscopic dilation is the first choice of treatment for all symptomatic benign esophageal strictures. If symptoms persist beyond 5 sessions of endoscopic dilation, the following are the available advanced techniques for the management of benign recalcitrant esophageal strictures:

1. Endoscopic dilation with intralesional steroid injection

2. Endoscopic dilation with intralesional mitomycin $\mathrm{C}$ injection

3. Endoscopic incisional therapy or stricturoplasty

4. Esophageal stent placement

5. Self-dilation

6. Surgical intervention

\section{Endoscopic dilation and steroid injection}

Topical injection of steroids (e.g., triamcinolone acetate) has been evaluated in the treatment of benign recalcitrant strictures that do not respond to repeat endoscopic dilations alone. It is postulated that, due to their anti-inflammatory properties and ability to interfere with collagen synthesis and fibrosis, 
steroid injections can reduce the inflammation and fibrosis of the strictures after endoscopic dilation [34]. A recent review mentioned a significant variation in the doses and concentrations used in the literature, ranging between $20 \mathrm{mg}, 32 \mathrm{mg}$, and $40 \mathrm{mg}$ per patient. One trial injected $5 \mathrm{mg}$ of triamcinolone every $10 \mathrm{~mm}$ into the stricture [35]. Our preference is endoscopic dilation following the submucosal injection of triamcinolone acetonide injections. A vial of $1 \mathrm{~mL}(40 \mathrm{mg} / \mathrm{mL})$ triamcinolone should be diluted 1:1 in normal saline $(1 \mathrm{~mL})$. An aliquot of $0.5 \mathrm{~mL}$ is injected into each quadrant of the stricture. For longer strictures, this could be repeated every $2 \mathrm{~cm}$. Although previous studies have been inconclusive, recent studies suggest a beneficial effect of steroid injection [36]. No more than 3 sessions of endoscopic dilation with steroid injections should be attempted since it is less likely to be beneficial [16]. If there is still no improvement in dysphagia symptoms, alternative treatment options should be considered.

In a recent RCT, 65 patients with anastomotic strictures were randomized into the study group (endoscopic dilation + steroid injection; $\mathrm{n}=33$ ) and placebo group (endoscopic dilation + saline injection; $\mathrm{n}=32$ ). After 6 months of follow up, the median number of dilations required to resolve the strictures in the study group was significantly lower than in the placebo group ( 2 vs. 4 dilations, $\mathrm{P}=0.001$ ). Moreover, among the study group, $36 \%$ remained recurrence-free, whereas only $16 \%$ of patients in the placebo group remained recurrence-free [37].

A meta-analysis of 3 RCTs of 144 patients (steroid and placebo groups, 72 patients in each) in benign anastomotic esophageal strictures showed that the mean number of dilations required for dysphagia relief was significantly lower in the steroid group (mean weighted difference of -1.62 , $95 \% \mathrm{CI}-2.73$ to $-0.50 ; \mathrm{P}=0.004)$ than in the control group. The steroid group also had a higher odds of being dysphagiafree at 6 months after initial dilation compared to the placebo group (2.36, 95\%CI 0.94-5.91; $\mathrm{P}=0.07$ ) [36]. A combination of dilation and steroid injection has shown a clinical benefit in reducing the need for repeat interventions and increasing the interval between endoscopic dilation from the above studies. However, larger multicenter RCTs are needed to prove the benefit of intralesional steroid injection in benign recalcitrant esophageal strictures.

\section{Endoscopic dilation and mitomycin C injection}

Mitomycin C is a chemotherapeutic agent used in the treatment of upper gastrointestinal cancers such as esophageal carcinoma, anal, breast, and bladder cancer. Due to its ability to inhibit fibroblasts and collagen formation, intralesional mitomycin $\mathrm{C}$ injection is considered as an alternative to topical steroids in the treatment of benign recalcitrant esophageal strictures [38]. Previous studies have used a variable concentration of mitomycin C (0.1-1 mg/mL) and different methods of the drug application for the treatment of benign recalcitrant esophageal strictures [39-41]. Cotton pledgets or sterile gauzes soaked in mitomycin $\mathrm{C}$ were rubbed against the area of the stricture for $3 \mathrm{~min}$ after dilation, or it was injected directly into the stricture after dilation by these prior studies. In our practice, mitomycin $\mathrm{C}(0.4 \mathrm{mg} / \mathrm{mL})$ is diluted in $1 \mathrm{~mL}$ of saline and then divided into aliquots of $0.5 \mathrm{~mL}$. One aliquot is injected into 4 quadrants of the narrowest part of the stricture after the dilation $[22,42]$. Serious adverse effects can occur with higher concentrations of topical therapy or endoscopic injection of mitomycin $\mathrm{C}$. The most common adverse events include intense pain, necrosis, and ulceration [42-45].

Previously published studies included a smaller number of patients, and the majority of them were in the pediatric population. The mitomycin $\mathrm{C}$ injection is observed to be particularly effective in corrosive strictures [46].

In a prospective pilot study, 9 patients were initially treated with endoscopic dilation alone for 8 months, followed by endoscopic dilation with mitomycin $\mathrm{C}$ injection, and followed up for 10 months. Following mitomycin $\mathrm{C}$ injection, the need for repeat dilation decreased from 1.5 dilations per month to 0.39 dilations per month. There was also a non-significant improvement in mean dysphagia score as well (from 3.2 to 2.6) [41].

In another prospective study, including 13 patients with recurrent pharyngoesophageal strictures after head-and-neck cancer treatment, the mitomycin Cinjection was observed to cause increased adverse events, including ulcers and intense neck pain, and therefore the trial was aborted prematurely [42]. Although the evidence in the pediatric population is promising, large RCTs are required before mitomycin $\mathrm{C}$ injection becomes a standard for treatment in adults with a benign recalcitrant esophageal stricture.

\section{Incisional therapy or stricturoplasty}

Incisional therapy is another promising modality in the treatment of benign recalcitrant esophageal strictures. Incisional therapy can be performed using a standard needleknife or an insulated tip electrosurgical knife (IT knife). Patients with short and elevated strictures made of fibrous scar tissues such as Schatzki ring and anastomotic strictures have favorable outcomes with this procedure. A standard needle-knife is a naked diathermy wire at the end of the device. The incision is made with electrocautery using electrosurgical generators. However, this technique can potentially increase the risk of esophageal perforation. To minimize the risk of perforation, an insulated ceramic tip is added that allows cutting only along the side. Table 2 shows studies that evaluated incisional therapy for anastomotic strictures. As described in Table 2, a total of 12 studies with 179 patients were treated with incisional therapy. The immediate clinical success after treatment ranged from $81-100 \%$, and the number of patients who were symptom-free ranged from $44-93 \%$ after a mean follow up of 24.7 months. The complication rate was reported to be $3.5-18 \%$ in these studies.

\section{Techniques and complications}

In this technique, 4-8 radial incisions are made in the stricture area using an electrosurgical needle knife. 
Table 2 Studies that evaluated incisional therapy for anastomotic strictures

\begin{tabular}{|c|c|c|c|c|c|c|}
\hline $\begin{array}{l}\text { Author and } \\
\text { Year }\end{array}$ & Technique & $\begin{array}{l}\text { Type of } \\
\text { stricture }\end{array}$ & $\begin{array}{l}\text { Patients } \\
\text { (n) }\end{array}$ & $\begin{array}{c}\text { Follow-up } \\
\text { duration (months) }\end{array}$ & $\begin{array}{l}\text { Clinical success Immediate } \\
\text { and at the end of follow up }\end{array}$ & $\begin{array}{l}\text { Complications } \\
(\%)\end{array}$ \\
\hline $\begin{array}{l}\text { Schubert } \\
2003[68]\end{array}$ & $\begin{array}{l}\text { Tip of polypectomy } \\
\text { snare with APC }\end{array}$ & $\begin{array}{l}\text { Treatment- } \\
\text { naïve }\end{array}$ & 15 & 23 & $100 \%$ and $93 \%$ & None \\
\hline $\begin{array}{l}\text { Simmons } \\
2006[69]\end{array}$ & Electrocautery incision & Refractory & 9 & 14 & $88.8 \%$ and $44.4 \%$ & None \\
\hline $\begin{array}{l}\text { Hordijk } \\
2006[49]\end{array}$ & Electrocautery incision & Refractory & 20 & 12 & $100 \%$ and $60 \%$ & None \\
\hline $\begin{array}{l}\text { Hordijk } \\
2009[70]\end{array}$ & Electrocautery incision & $\begin{array}{l}\text { Treatment- } \\
\text { naïve }\end{array}$ & $\begin{array}{c}\text { EIT } \\
(n=31) \\
\text { SB }(n=31)\end{array}$ & 6 & $\begin{array}{l}(80.6 \% \text { vs. } 67.7 \%) \\
\text { Treatment failure- EIT arm } \\
-1 ; \text { SB arm - } 5\end{array}$ & None \\
\hline $\begin{array}{l}\text { Lee } \\
2009[50]\end{array}$ & $\begin{array}{l}\text { Insulated tip knife, } \\
\text { endoscopic hood/cap }\end{array}$ & $\begin{array}{l}\text { Treatment- } \\
\text { naïve }\end{array}$ & 24 & 24 & $100 \%$ and $87.5 \%$ & None \\
\hline $\begin{array}{l}\text { Muto } \\
2012[71]\end{array}$ & Electrocautery incision & Refractory & $\begin{array}{l}\text { EIT }-32 \\
\text { EBD - } 22\end{array}$ & $\begin{array}{c}\text { EIT }-12 \\
\text { EBD }-17.2\end{array}$ & $\begin{array}{l}\text { EIT } 81.3 \% \text { and } 62 \% \\
\text { EBD } 93.8 \% \text { and } 19.8 \%\end{array}$ & $3.5 \%$ \\
\hline $\begin{array}{l}\text { Tan } \\
2016[72]\end{array}$ & Electrocautery incision & $\begin{array}{l}\text { Refractory } \\
\text { anastomotic }\end{array}$ & 13 & 24 & $100 \%$ and $60 \%$ & NA \\
\hline $\begin{array}{l}\text { Pross } \\
1998[73]\end{array}$ & Electrocautery incision & Anastomotic & 5 & NA & $100 \%$ and NA & None \\
\hline $\begin{array}{l}\text { Hagiwara } \\
1999[74]\end{array}$ & Electrocautery incision & $\begin{array}{l}\text { Refractory } \\
\text { anastomotic }\end{array}$ & 6 & NA & $83.33 \%$ and NA & NA \\
\hline $\begin{array}{l}\text { Brandimarte } \\
2002[75]\end{array}$ & Electrocautery incision & $\begin{array}{l}\text { Refractory } \\
\text { anastomotic }\end{array}$ & 6 & 24 & $100 \%$ and $36 \%$ & None \\
\hline $\begin{array}{l}\text { Disario } \\
2002[76]\end{array}$ & Electrocautery incision & Schatzki ring & 11 & 72 & $100 \%$ and $36 \%$ & $18 \%$ \\
\hline $\begin{array}{l}\text { Burdick } \\
1993 \text { [77] }\end{array}$ & Electrocautery incision & Schatzki ring & 7 & 36 & $100 \%$ and $85.7 \%$ & None \\
\hline
\end{tabular}

EIT, endoscopic incisional therapy; SB, Savary-Gilliard ${ }^{\circledR}$; EBD, endoscopic balloon dilatation; NA, not applicable; APC, argon plasma coagulation

It is recommended that the depth of the incision should not exceed the continuity of the esophageal lumen. The remaining fibrous scar tissue between the incisions can be excised. Patients with short elevated fibrous strictures $(1-2 \mathrm{~cm})$ are ideal patients for this procedure. A combination of incisional therapy followed by balloon dilation during the same session has been evaluated in small case reports and case series $[47,48]$. However, the data is inadequate to make recommendations on whether this technique is effective and safe. Fig. 3 shows a benign recalcitrant esophageal stricture treated with needle knife stricturoplasty, and Fig. 4 shows pre-treatment and post-treatment views of the benign recalcitrant esophageal stricture with IT knife stricturoplasty.

In a prospective study, 20 patients with anastomotic esophageal strictures refractory to balloon dilation were treated with electrocautery incisional therapy. Twelve patients who had short segment strictures remained dysphagia-free at the end of 1 year, and the remaining 8 patients who had longsegment strictures required at least 3 sessions of incisional therapy [49]. There were no perforations.

In another retrospective study, incisional therapy was used as a treatment in 24 patients with benign recalcitrant esophageal strictures. With just 1 session of incisional therapy, $87.5 \%$ of

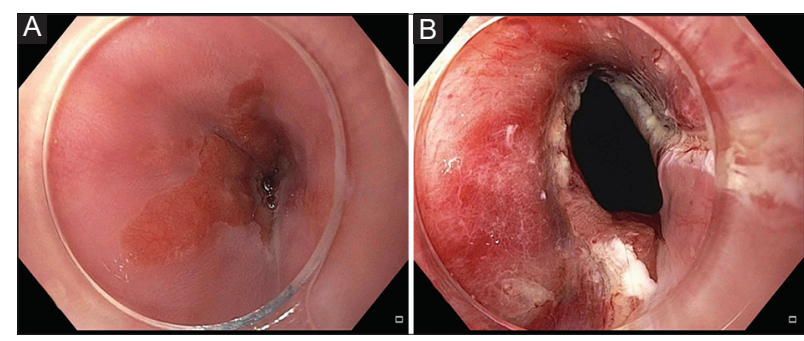

Figure 3 Benign recalcitrant esophageal stricture before (A) and after (B) standard needle knife stricturoplasty

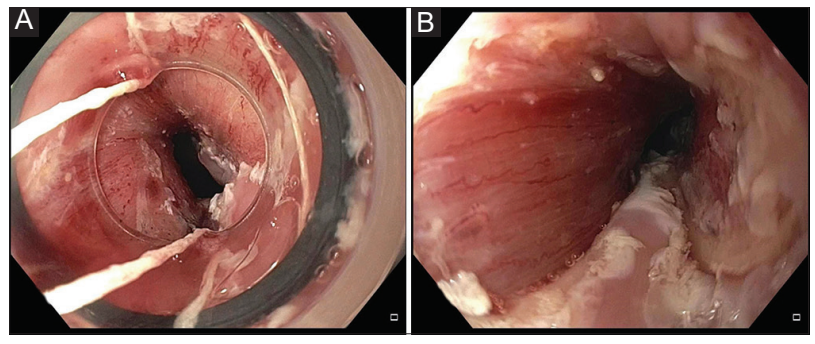

Figure 4 Pre-treatment (A) and post-treatment (B) appearance of the benign recalcitrant esophageal stricture with IT knife stricturoplasty

the patients remained free of dysphagia at the end of 2 years. It was also observed that recurrence of the stricture was more 
common among the patients who had long-segment strictures (66\%) compared to short-segment strictures (4\%) [50].

\section{Stent placement}

Esophageal stents can be placed as a treatment for the management of benign recalcitrant esophageal strictures. Various types of stents have been used in the treatment of benign recalcitrant esophageal strictures, including self-expanding plastic stent (SEPS), fully-covered self-expanding metal stents (SEMS), partially-covered self-expanding metal stents, lumen apposing metal stents (LAMS), and biodegradable stents. The prior studies on outcomes of placement of fully-covered SEMS, SEPS, and biodegradable stents are shown in Tables 3-5. Metal stents are used more commonly than plastic stents for the treatment of benign recalcitrant esophageal strictures as plastic stents can cause high rates of migration (62\%), endoscopic reintervention (21\%), and low long-term relief of dysphagia (30\%) [51]. Therefore, our article will focus on the metal stents, first discussing fully-covered SEMS and LAMS, as these are the most commonly used in practice.

\section{Techniques and complications}

First, the guidewire is passed through the stricture, and then dilation of the stricture can be performed by either balloon or SG dilator if required to pass the 7-Fr stent delivery apparatus. Radioopaque markers (for example, paper pins) are placed at distal and proximal edges of the stricture. Under fluoroscopic guidance, a fully-covered SEMS is deployed, and adequate placement is verified with endoscopy. Alternatively, the fully-covered SEMS can also be placed under direct visualization of endoscopy without the aid of fluoroscopy. All patients receive PPI after the stent placement if it results in a permanently open gastroesophageal junction leading to the risk of reflux and aspiration. However, this may not be necessary if the stent does not bridge the gastroesophageal junction. The European Society of Gastrointestinal Endoscopy (ESGE) recommends fully-covered SEMS should be left in place for a maximum of 12 weeks to minimize the risk of hyperplastic tissue and stent embedment [38]. These stents can be removed with rat-tooth forceps when needed (Fig. 5).

The presence of a stent can reduce the need for repeated interventions, although stents have their own unique procedural and stent-related complications. Immediate complications after stent placement (occurring within $24 \mathrm{~h}$ ) are chest pain, perforation, bleeding, and stent malposition [52]. Early complications (occurring between 2 and 4 weeks) include retrosternal pain, bleeding, perforation, globus sensation, worsening gastroesophageal reflux disease symptoms, and stent migration [52]. The most common complication during both the early and late phase is stent migration (7-75\%) [53]. Severe chest pain is reported in $14 \%$ of the patients [53].

Late complications (occurring after 2-4 weeks) include stent migration, perforation, food impaction, esophageal fistula formation, and stricture recurrence [54]. A delayed complication may occur in 53-65\% of the cases [55,56]. Many issues with stent migration are now overcome by stent fixation to the esophageal mucosa with sutures. However, the use of sutures can add up to the overall cost of the treatment and can make it expensive.

The literature on the use of LAMS in benign recalcitrant esophageal strictures is scarce and has been studied in a small number of patients. The LAMS was originally designed for drainage of pancreatic pseudocysts. However, they are now gaining popularity for the treatment of short strictures $(<1 \mathrm{~cm})$. The studies showed LAMS can be effective in relieving dysphagia symptoms in benign recalcitrant esophageal strictures and can be cost-effective in managing benign recalcitrant esophageal strictures when dilations fail [57-60]. The presence of short and wide flares provides more stability and reduces the risk of stent migration. Due to the short length of LAMS, their use is limited to short strictures $(<1 \mathrm{~cm})$. The wide flares at the end of the stent can cause constant irritation to the esophageal mucosa proximal to the stricture and can lead to ulceration, pain, bleeding, and fistula formation. Therefore these stents may not be tolerated by all and should be removed within 12 weeks. Currently, the data is limited and larger studies are required to know the exact outcomes of LAMS.

Previous experience showed that due to tissue ingrowth, partially-covered SEMS have a lower chance of stent migration compared to fully-covered SEMS. However, partially-covered SEMS have significantly higher short-term (35.3 vs. $8.7 \%$, $\mathrm{P}=0.053)$ and lower long-term clinical success (23.5\% vs. $34.7 \%$, $\mathrm{P}=0.0505)$ compared to fully-covered SEMS [61]. The use of a partially-covered metal stent is associated with a high rate of tissue ingrowth into the stent mesh leading to the embedding of the stent in the esophageal mucosa. Although tissue ingrowth reduces the chance of stent migration, it makes it difficult to remove the stent. A stent-in-stent technique (placement of a slightly larger stent in the embedded stent leads to pressure necrosis of the ingrown tissue) has been used to extract the stents when tissue ingrowth occurs. Another complication of the partially-covered stent is stricture recurrence. Therefore, fully-covered SEMS are preferred. Because of all these reasons, ESGE recommends the use of fully-covered SEMS over partially-covered SEMS [38].

While SEMS and SEPS need to be removed after symptom resolution, biodegradable stents do not need to be removed. However, they have a weaker radial distensile force and, therefore, may require further endoscopic dilation after stent placement. The biodegradable stents SX Ella BD Stent (Ella-CS, Hradec Kralove, Czech Republic) usually retain their integrity and radial

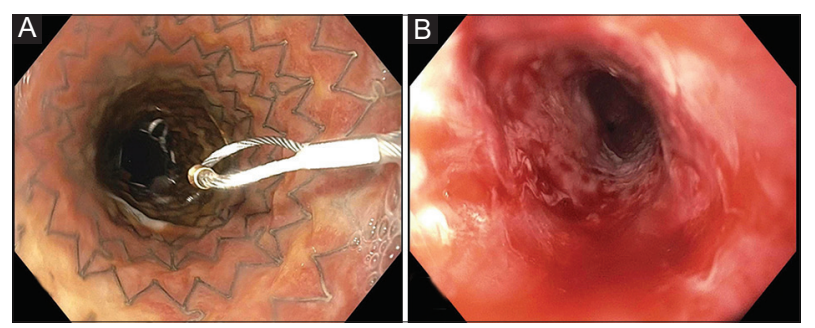

Figure 5 Benign recalcitrant esophageal stricture after self-expanding metal stent placement (A) and after stent removal (B) 
8 U. Boregowda et al

Table 3 Studies that have evaluated fully covered SEMS in benign esophageal strictures

\begin{tabular}{|c|c|c|c|c|c|c|c|c|}
\hline $\begin{array}{l}\text { Author, } \\
\text { year }\end{array}$ & Study design & $\begin{array}{l}\text { Patients } \\
\text { (n) }\end{array}$ & $\begin{array}{l}\text { Stricture etiology, } \\
\text { n (\%) }\end{array}$ & Stent type & $\begin{array}{l}\text { Median stent placement } \\
\text { time, days (range) }\end{array}$ & $\begin{array}{c}\text { Technical } \\
\text { success } \\
\text { n (\%) }\end{array}$ & $\begin{array}{l}\text { Complications } \\
\mathrm{n}(\%)\end{array}$ & $\begin{array}{l}\text { Migration, } \\
\text { n (\%) }\end{array}$ \\
\hline $\begin{array}{l}\text { Song, } \\
2000[78]\end{array}$ & Prospective & 25 & $\begin{array}{l}\text { Peptic } 1(4) \\
\text { Caustic } 22(88) \\
\text { Radiotherapy } 1(4) \\
\text { Surgical } 0 \\
\text { Other } 1(4)\end{array}$ & FC-SEMS & 29 & $12(48)$ & $17(68)$ & $3(12)$ \\
\hline $\begin{array}{l}\text { Kim, } \\
2009 \text { [79] }\end{array}$ & Retrospective & 51 & $\begin{array}{l}\text { Peptic } 1(2) \\
\text { Caustic } 44(86) \\
\text { Radiotherapy } 2(4) \\
\text { Surgical } 2(4) \\
\text { Other } 3(6)\end{array}$ & FC-SEMS & 56 & $13(26)$ & $14(27)$ & $13(26)$ \\
\hline $\begin{array}{l}\text { Bakken, } \\
2010[80]\end{array}$ & Retrospective & 25 & $\begin{array}{l}\text { Peptic } 7 \text { (28) } \\
\text { Caustic } 0 \\
\text { Radiotherapy } 8(32) \\
\text { Surgical } 10(40) \\
\text { Other } 0\end{array}$ & FC-SEMS & $67(0-279)$ & $13(52)$ & $5(20)$ & $11(44)$ \\
\hline $\begin{array}{l}\text { Eloubeid, } \\
2011 \text { [81] }\end{array}$ & Retrospective & 19 & $\begin{array}{l}\text { Peptic } 4(21) \\
\text { Caustic } 2(11) \\
\text { Radiotherapy } 2 \text { (11) } \\
\text { Surgical } 9(47) \\
\text { Other } 2(11)\end{array}$ & FC-SEMS & $64(6-300)$ & $4(21)$ & $5(26)$ & $7(37)$ \\
\hline $\begin{array}{l}\text { Hirdes, } \\
2012[82]\end{array}$ & Prospective & 15 & $\begin{array}{l}\text { Peptic } 6(40) \\
\text { Caustic } 3(20) \\
\text { Radiotherapy } 2 \text { (13) } \\
\text { Surgical } 0 \\
\text { Other } 4 \text { (27) }\end{array}$ & FC-SEMS & $61(13-222)$ & 0 & $5(33)$ & $7(47)$ \\
\hline $\begin{array}{l}\text { Liu, } \\
2012[83]\end{array}$ & Retrospective & 24 & $\begin{array}{l}\text { Peptic } 0 \\
\text { Caustic } 0 \\
\text { Radiotherapy } 0 \\
\text { Surgical } 24(100) \\
\text { Other } 0\end{array}$ & FC-SEMS & $74(63-84)$ & $18(75)$ & 0 & $1(4)$ \\
\hline $\begin{array}{l}\text { Canena, } \\
2012[84]\end{array}$ & Prospective & 30 & $\begin{array}{l}\text { Peptic } 7(23) \\
\text { Caustic } 3(10) \\
\text { Radiotherapy } 2(7) \\
\text { Surgical } 13(43) \\
\text { Other } 5(17)\end{array}$ & $\begin{array}{l}\text { FC-SEMS, } \\
\text { SEPS, } \\
\text { BDS }\end{array}$ & $\begin{array}{c}\text { FC-SEMS } 90 \\
\text { SEPS } 90 \\
\text { BDS } 74(63-84)\end{array}$ & $8(27)$ & $2(7)$ & $11(37)$ \\
\hline $\begin{array}{l}\text { Chaput, } \\
2013 \text { [85] }\end{array}$ & Prospective & 41 & $\begin{array}{l}\text { Peptic } 16(39) \\
\text { Caustic } 3(7) \\
\text { Radiotherapy } 8(20) \\
\text { Surgical } 12(29) \\
\text { Other } 2(5)\end{array}$ & FC-SEMS & $58(20-140)$ & $21(51)$ & $5(12)$ & $12(29)$ \\
\hline $\begin{array}{l}\text { Dan, } \\
2014 \text { [86] }\end{array}$ & Retrospective & 17 & $\begin{array}{l}\text { Peptic } 2 \text { (12) } \\
\text { Caustic } 0 \\
\text { Radiotherapy } 3(18) \\
\text { Surgical } 9 \text { (52) } \\
\text { Other } 3 \text { (18) }\end{array}$ & FC-SEMS & $71(1-65)$ & $5(29)$ & 0 & $9(53)$ \\
\hline Lu, 2019 & Retrospective & 20 & $\begin{array}{l}\text { Peptic } \\
\text { Caustic } \\
\text { Radiotherapy } \\
\text { Surgical }\end{array}$ & SEMS & $29(7-67)$ & $7(35 \%)$ & $9(47 \%)$ & $6(8 \%)$ \\
\hline
\end{tabular}

FC-SEMS, fully covered self-expanding metal stents, SEMS, self-expanding metal stents, BDS, biodegradable stents; SEPS, self-expanding plastic stent

distensile force for 6-8 weeks and disintegrate in 11-12 weeks from implantation [9]. A systemic review and meta-analysis of 18 studies involving 444 patients evaluated the outcomes of 3 different types of stent (SEPS, SEMS, and biodegradable) in benign recalcitrant strictures. The study showed that the pooled clinical success rate of $46.2 \%$ vs. $40.1 \%$ vs. $32.9 \%$ in SEPS, SEMS, and biodegradable stents, respectively. There was no significant difference in the pooled migration rate of $33.3 \%$ vs. 
Table 4 Studies that have evaluated self-expanding plastic stents

\begin{tabular}{|c|c|c|c|c|c|c|c|c|}
\hline Author, year & Study design & $\begin{array}{l}\text { Patients } \\
\text { (n) }\end{array}$ & $\begin{array}{l}\text { Stricture etiology, } \\
\text { n (\%) }\end{array}$ & Stent type & $\begin{array}{l}\text { Median stent } \\
\text { placement time, } \\
\text { days (range) }\end{array}$ & $\begin{array}{c}\text { Technical } \\
\text { success } \\
\text { n (\%) }\end{array}$ & $\begin{array}{c}\text { Complications } \\
\text { n (\%) }\end{array}$ & $\begin{array}{l}\text { Migration, } \\
\text { n (\%) }\end{array}$ \\
\hline $\begin{array}{l}\text { Repici, } \\
2004 \text { [87] }\end{array}$ & Prospective & 15 & $\begin{array}{l}\text { Peptic } 2(13) \\
\text { Caustic } 5 \text { (33) } \\
\text { Radiotherapy } 4 \text { (27) } \\
\text { Surgical } 4 \text { (27) } \\
\text { Other } 0\end{array}$ & SEPS & 42 & $12(80)$ & $5(33)$ & $1(7)$ \\
\hline $\begin{array}{l}\text { Evrard, } \\
2004 \text { [88] }\end{array}$ & Prospective & 12 & $\begin{array}{l}\text { Peptic } 2 \text { (17) } \\
\text { Caustic } 3 \text { (25) } \\
\text { Radiotherapy } 3 \text { (25) } \\
\text { Surgical } 4 \text { (33) } \\
\text { Other } 0\end{array}$ & SEPS & - & $8(67)$ & $2(17)$ & $8(67)$ \\
\hline $\begin{array}{l}\text { Karbowsky, } \\
2007 \text { [89] }\end{array}$ & Retrospective & 14 & $\begin{array}{l}\text { Peptic } 4 \text { (29) } \\
\text { Caustic } 1 \text { (7) } \\
\text { Radiotherapy } 2 \text { (14) } \\
\text { Surgical } 5(36) \\
\text { Other } 2(15)\end{array}$ & SEPS & $52(14-266)$ & $5(36)$ & $2(14)$ & $6(43)$ \\
\hline $\begin{array}{l}\text { Dua, } \\
2008 \text { [90] }\end{array}$ & Prospective & 38 & $\begin{array}{l}\text { Peptic } 2(6) \\
\text { Caustic } 8(21) \\
\text { Radiotherapy } 7 \text { (18) } \\
\text { Surgical } 8(21) \\
\text { Other } 13(34)\end{array}$ & SEPS & 28 & $12(32)$ & $12(32)$ & $8(21)$ \\
\hline $\begin{array}{l}\text { Martin, } \\
2008 \text { [91] }\end{array}$ & Retrospective & 18 & $\begin{array}{l}\text { Peptic } 2(10) \\
\text { Caustic } 1(6) \\
\text { Radiotherapy } 3 \text { (17) } \\
\text { Surgical } 12(67) \\
\text { Other } 0\end{array}$ & SEPS & 93 & $17(94)$ & $1(6)$ & $1(6)$ \\
\hline $\begin{array}{l}\text { Oh, } \\
2010 \text { [92] }\end{array}$ & Retrospective & 13 & $\begin{array}{l}\text { Peptic } 0 \\
\text { Caustic } 0 \\
\text { Radiotherapy } 1(8) \\
\text { Surgical } 11(84) \\
\text { Other } 1 \text { (8) }\end{array}$ & SEPS & $82(30-257)$ & $3(23)$ & 0 & $7(54)$ \\
\hline $\begin{array}{l}\text { Van Boeckel, } \\
2011 \text { [93] }\end{array}$ & Prospective & 38 & $\begin{array}{l}\text { Peptic } 7(18) \\
\text { Caustic } 6(16) \\
\text { Radiotherapy } 7 \text { (18) } \\
\text { Surgical } 13(35) \\
\text { Other } 5(13)\end{array}$ & $\begin{array}{l}\text { SEPS, } \\
\text { BDS }\end{array}$ & $\begin{array}{c}42 \text { SEPS } \\
74(63-84) \text { BDS }\end{array}$ & $12(32)$ & $6(16)$ & $9(24)$ \\
\hline $\begin{array}{l}\text { Canena, } \\
2012[84]\end{array}$ & Prospective & 30 & $\begin{array}{l}\text { Peptic } 7(23) \\
\text { Caustic } 3(10) \\
\text { Radiotherapy } 2(7) \\
\text { Surgical } 13(43) \\
\text { Other } 5(17)\end{array}$ & $\begin{array}{l}\text { FC-SEMS, } \\
\text { SEPS, } \\
\text { BDS }\end{array}$ & $\begin{array}{c}\text { FC-SEMS } 90 \\
\text { SEPS } 90 \\
\text { BDS } 74(63-84)\end{array}$ & $8(27)$ & $2(7)$ & $11(37)$ \\
\hline
\end{tabular}

FC-SEMS, fully covered self-expanding metal stents, SEMS, self-expanding metal stents, BDS, biodegradable stent; SEPS, self-expanding plastic stent

$31.5 \%$ vs. $15.3 \%$ in SEPS, SEMS, and biodegradable stent groups, respectively. The adverse event rate was $20.6 \%$ (95\%CI $15.3-$ $28.1 \%$ ) and with no significant difference in adverse event rates between stent types with $19.4 \%$ vs. $21.9 \%$ vs. $21.9 \%$ in SEPS, SEMS, and biodegradable stent groups respectively [62].

\section{Self-dilation}

Esophageal self-dilation has been used for the treatment of benign refractory esophageal strictures for more than 5 decades
$[63,64]$. Long-term self-dilation can be considered in selected patients with short-segment and non-angulated benign recalcitrant strictures. This may not be appropriate for complex esophageal strictures, which are longer, irregular, tortuous, or angulated strictures. Repeat self-dilation of benign recalcitrant esophageal strictures is considered when all the endoscopic dilation strategies mentioned above fail to improve dysphagia symptoms. Patient acceptance and participation is a significant challenge in choosing self-dilation. However, with experience, self-dilation can be a long-term effective measure in managing benign recalcitrant esophageal strictures. Self-dilation allows 
Table 5 Studies that have evaluated biodegradable stents in benign recalcitrant esophageal strictures

\begin{tabular}{|c|c|c|c|c|c|c|c|c|}
\hline Author, year & Study design & $\begin{array}{l}\text { Patients } \\
\text { (n) }\end{array}$ & $\begin{array}{l}\text { Stricture etiology, } \\
\text { n (\%) }\end{array}$ & Stent type & $\begin{array}{l}\text { Median stent } \\
\text { placement time, } \\
\text { days (range) }\end{array}$ & $\begin{array}{c}\text { Technical } \\
\text { success } \\
\text { n (\%) }\end{array}$ & $\begin{array}{l}\text { Complications } \\
\text { n (\%) }\end{array}$ & $\begin{array}{l}\text { Migration, } \\
\mathrm{n}(\%)\end{array}$ \\
\hline $\begin{array}{l}\text { Repici, } \\
2010[94]\end{array}$ & Prospective & 21 & $\begin{array}{l}\text { Peptic } 7(33) \\
\text { Caustic } 2(10) \\
\text { Radiotherapy } 5(24) \\
\text { Surgical } 5(24) \\
\text { Other } 2(10)\end{array}$ & BDS & $74(63-84)$ & $9(43)$ & $3(14)$ & $2(10)$ \\
\hline $\begin{array}{l}\text { Van Boeckel } \\
2011 \text { [93] }\end{array}$ & Prospective & 38 & $\begin{array}{l}\text { Peptic } 7(18) \\
\text { Caustic } 6(16) \\
\text { Radiotherapy } 7 \text { (18) } \\
\text { Surgical } 13(35) \\
\text { Other } 5(13)\end{array}$ & $\begin{array}{l}\text { SEPS, } \\
\text { BDS }\end{array}$ & $\begin{array}{c}42 \text { SEPS } \\
74(63-84) \text { BDS }\end{array}$ & $12(32)$ & $6(16)$ & $9(24)$ \\
\hline $\begin{array}{l}\text { Hirdes, } \\
2012 \text { [95] }\end{array}$ & Prospective & 28 & $\begin{array}{l}\text { Peptic } 9(32) \\
\text { Caustic } 2(7) \\
\text { Radiotherapy } 3(11) \\
\text { Surgical } 7(25) \\
\text { Other } 7 \text { (25) }\end{array}$ & BDS & 42 & $7(25)$ & $8(29)$ & $3(11)$ \\
\hline $\begin{array}{l}\text { Canena } \\
2012[84]\end{array}$ & Prospective & 30 & $\begin{array}{l}\text { Peptic } 7(23) \\
\text { Caustic } 3(10) \\
\text { Radiotherapy } 2(7) \\
\text { Surgical } 13(43) \\
\text { Other } 5(17)\end{array}$ & $\begin{array}{l}\text { FC-SEMS, } \\
\text { SEPS, } \\
\text { BDS }\end{array}$ & $\begin{array}{c}\text { FC-SEMS } 90 \\
\text { SEPS } 90 \\
\text { BDS } 74(63-84)\end{array}$ & $8(27)$ & $2(7)$ & $11(37)$ \\
\hline
\end{tabular}

FC-SEMS, fully covered self-expanding metal stents, SEMS, self-expanding metal stents, BDS, biodegradable; SEPS, self-expanding plastic stent

patients to regain autonomy and reduces the need for repeated endoscopic dilation [65].

The physician usually initiates the procedure, and the patient is taught over time. The procedure involves periodic dilation of the stricture using a bougie of a predetermined size. Commonly, a bougie size $>14 \mathrm{~mm}$ is recommended. A successful self-dilation with a size $>14 \mathrm{~mm}$ allows patients to have a solid diet. Sometimes patients may even perform daily dilation. A frequent and regular self-dilation can eventually lead to a significantly longer dysphagia-free period [24]. However, the choice of patients is important. Patients with short, straight strictures are easier to selfdilate compared to long, angulated complex strictures. Self-dilation of more complex strictures carries a high risk of injury, as the bougie is not guided by a guide-wire. Common complications of self-dilation are esophageal perforation, bleeding, and pain [64-66].

One recent study reported data on self-dilation in 30 patients with benign recalcitrant esophageal strictures. Prior to self-dilation, patients required an average of 12 dilations were performed annually. The study reported a $90 \%$ clinical success with self-dilation after a median follows up of 37 months [64]. A recent case series involving 17 patients with post-surgical and caustic strictures also reported a technical success of $94 \%$ and a clinical success of $94 \%$ with a median to follow up of 17.6 months [65]. All patients were able to tolerate solid food (median diameter of the bougienage used $14 \mathrm{~mm}$ ).

Another large retrospective study reported results of selfdilation in 52 patients with benign recurrent esophageal strictures. In this study, the median number of endoscopic interventions improved from 9.5 (range 5-30) to 0 (range

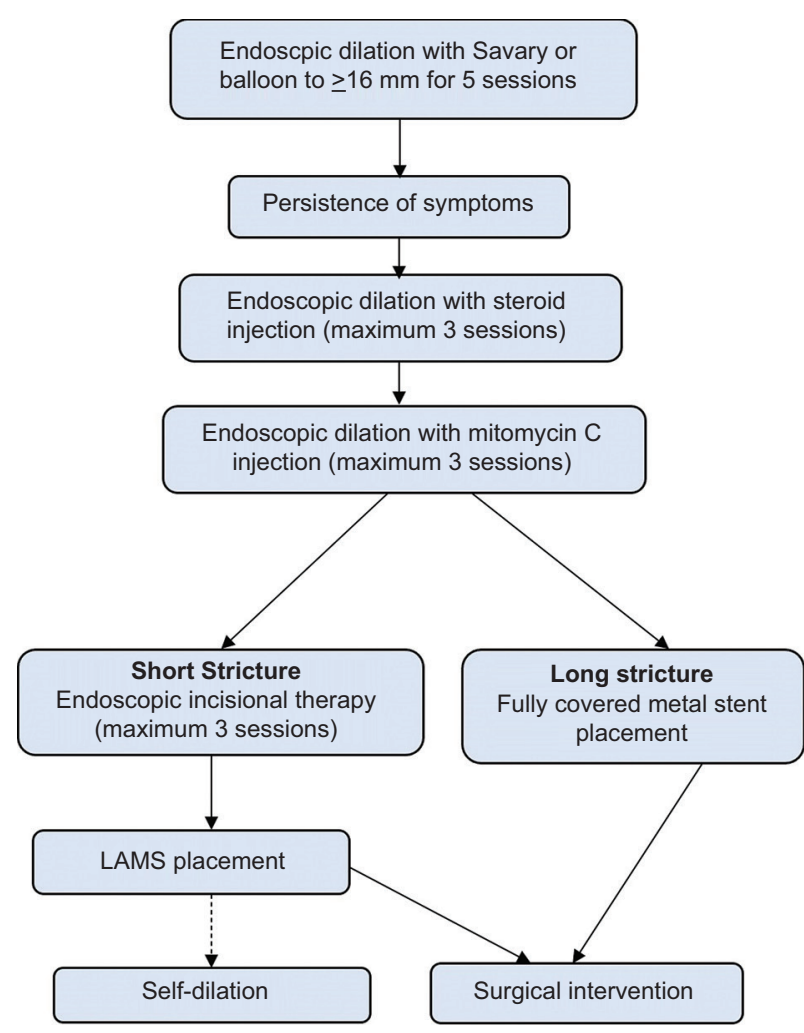

Figure 6 Algorithm for management of benign esophageal strictures LAMS, lumen apposing metal stent

0 -3) with a median intervention-free duration of 417 days (interquartile range 256-756 days) [66]. 
Success rates of the above-mentioned studies suggest that self-dilation can be an effective treatment strategy for the treatment of benign recalcitrant esophageal strictures. Patient selection and initial training play a significant role in the success of self-dilation.

\section{Surgery}

The treatment of benign recalcitrant esophageal strictures can be surgery, but it should be the last resort as it can cause serious morbidity and mortality. Moreover, it is a technically difficult procedure as surgery usually requires the opening of a thorax or abdomen based on the location of esophageal strictures. Strictures in the proximal and mid esophagus are more difficult to operate than in the distal esophagus due to proximity to the airway $[23,24]$. There are different kinds of surgical procedures ranging from minimally invasive procedures, like transgastric resection of the stricture with endoscopic assistance, to complex, like colonic or jejunal interposition [18]. In a patient with esophageal stricture secondary to caustic injury, esophageal resection is considered the next step when endoscopic treatment, including multiple serial dilatations, fails to sustain the widening of esophageal diameter after treatment for 3-6 months [67]. Since injury due to caustic ingestion is usually intraluminal and mostly affects the distal esophagus, the patients develop less scarred tissue, and anastomosis is usually less complicated. After esophagectomy, reconstruction of the gastrointestinal tract is done by either gastric pull-up or colonic repositioning. The gastric pull-up is the procedure of choice as it is easier to perform. Colonic or jejunal interposition is preferred if there is severe damage to gastric tissue, which hinders the use for the gastric pull-up [67].

\section{Concluding remarks}

The management of benign recalcitrant esophageal strictures can be long, complicated, and are associated with poor outcomes. The majority of the benign simple or complex strictures can be treated with PPI and endoscopic dilation. Maximizing the dose of PPI and applying frequent aggressive dilations of benign simple or complex strictures early, may prevent them from progressing to benign recalcitrant esophageal strictures. Having a methodical stepwise approach is important for better outcomes of the treatment of benign recalcitrant esophageal strictures. Based on the literature review and our experience of treating benign recalcitrant esophageal strictures, we have formulated an algorithm for their management (Fig. 6). The patients should be informed about the prognosis as their compliance with repeated treatment sessions is one of the key factors for success. The management should be undertaken in a tertiary care center with good surgical support and by experienced advanced endoscopists who have the knowledge and skills to use various endoscopic tools and electrocautery settings.

\section{References}

1. Dryden GW, McClave SA. Methods of treating dysphagia caused by benign esophageal strictures. Tech Gastrointest Endosc 2001;3:135-143.

2. Pasha SF, Acosta RD, Chandrasekhara V, et al. The role of endoscopy in the evaluation and management of dysphagia. Gastrointest Endosc 2014;79:191-201.

3. Siersema PD. Treatment options for esophageal strictures. Nat Clin Pract Gastroenterol Hepatol 2008;5:142-152.

4. Mullick T, Falk GW. Esophageal strictures: etiology and diagnosis. Tech Gastrointest Endosc 2001;3:128-134.

5. Castell DO, Donner MW. Evaluation of dysphagia: a careful history is crucial. Dysphagia 1987;2:65-71.

6. Siersema PD. Stenting for benign esophageal strictures. Endoscopy 2009;41:363-373.

7. Desai JP, Moustarah F. Esophageal Stricture. StatPearls. Treasure Island (FL): StatPearls Publishing Copyright @ 2020 , StatPearls Publishing LLC. 2020.

8. Ramasamy K, Gumaste VV. Corrosive ingestion in adults. J Clin Gastroenterol 2003;37:119-124.

9. Poincloux L, Rouquette O, Abergel A. Endoscopic treatment of benign esophageal strictures: a literature review. Expert Rev Gastroenterol Hepatol 2017;11:53-64.

10. Sami SS, Haboubi HN, Ang Y, et al. UK guidelines on oesophageal dilatation in clinical practice. Gut 2018;67:1000-1023.

11. Adler DG, Siddiqui AA. Endoscopic management of esophageal strictures. Gastrointest Endosc 2017;86:35-43.

12. Lew RJ, Kochman ML. A review of endoscopic methods of esophageal dilation. J Clin Gastroenterol 2002;35:117-126.

13. Shah JN. Benign refractory esophageal strictures: widening the endoscopist's role. Gastrointest Endosc 2006;63:164-167.

14. Agarwalla A, Small AJ, Mendelson AH, et al. Risk of recurrent or refractory strictures and outcome of endoscopic dilation for radiationinduced esophageal strictures. Surg Endosc 2014;29:1903-1912.

15. Kochman ML, McClave SA, Boyce HW. The refractory and the recurrent esophageal stricture: a definition. Gastrointest Endosc 2005;62:474-475.

16. Siersema PD, de Wijkerslooth LR. Dilation of refractory benign esophageal strictures. Gastrointest Endosc 2009;70:1000-1012.

17. Said A, Brust DJ, Gaumnitz EA, et al. Predictors of early recurrence of benign esophageal strictures. Am J Gastroenterol 2003;98:12521256.

18. Ferguson DD. Evaluation and management of benign esophageal strictures. Dis Esophagus 2005;18:359-364.

19. Ruigómez A, García Rodríguez LA, Wallander MA, et al. Esophageal stricture: incidence, treatment patterns, and recurrence rate. Am J Gastroenterol 2006;101:2685-2692.

20. Smith PM, Kerr GD, Cockel R, et al. A comparison of omeprazole and ranitidine in the prevention of recurrence of benign esophageal stricture. Restore Investigator Group. Gastroenterology 1994;107:1312-1318.

21. Gümürdülü Y, Karakoç E, Kara B, et al. The efficiency of sucralfate in corrosive esophagitis: a randomized, prospective study. Turk J Gastroenterol 2010;21:7-11.

22. Siersema PD. How to approach a patient with refractory or recurrent benign esophageal stricture. Gastroenterology 2019;156:7-10.

23. van Boeckel PG, Siersema PD. Refractory esophageal strictures: what to do when dilation fails. Curr Treat Options Gastroenterol 2015; 13:47-58.

24. Baron TH. Management of benign esophageal strictures. Gastroenterol Hepatol 2011;7:46-49.

25. Carlson DA, Hirano I. Narrow-caliber esophagus of eosinophilic esophagitis: difficult to define, resistant to remedy. Gastrointest Endosc 2016;83:1149-1150.

26. Scolapio JS, Pasha TM, Gostout CJ, et al. A randomized prospective 
study comparing rigid to balloon dilators for benign esophageal strictures and rings. Gastrointest Endosc 1999;50:13-17.

27. Standards of Practice C, Egan JV, Baron TH, et al. Esophageal dilation. Gastrointest Endosc 2006;63:755-760.

28. Richter JE. Rule of three for esophageal dilation: like the tortoise versus the rabbit, low and slow is our friend and our patients' win. Gastrointest Endosc 2017;85:338-339.

29. Grooteman KV, Wong Kee Song LM, Vleggaar FP, et al. Nonadherence to the rule of 3 does not increase the risk of adverse events in esophageal dilation. Gastrointest Endosc 2017;85:332-337, e331.

30. van Halsema EE, Noordzij IC, van Berge Henegouwen MI, et al. Endoscopic dilation of benign esophageal anastomotic strictures over $16 \mathrm{~mm}$ has a longer lasting effect. Surg Endosc 2017;31:18711881.

31. Blount KJ, Lambert DL, Shaffer HA, Jr., et al. Fluoroscopically guided balloon dilation of the esophagus. Semin Intervent Radiol 2010;27:232-240.

32. Raymondi R, Pereira-Lima JC, Valves A, et al. Endoscopic dilation of benign esophageal strictures without fluoroscopy: experience of 2750 procedures. Hepatogastroenterology 2008;55:1342-1348.

33. Josino IR, Madruga-Neto AC, Ribeiro IB, et al. Endoscopic dilation with bougies versus balloon dilation in esophageal benign strictures: systematic review and meta-analysis. Gastroenterol Res Pract 2018;2018:5874870.

34. Hirdes MM, van Hooft JE, Koornstra JJ, et al. Endoscopic corticosteroid injections do not reduce dysphagia after endoscopic dilation therapy in patients with benign esophagogastric anastomotic strictures. Clin Gastroenterol Hepatol 2013;11:795801, e791.

35. Zhang YW, Wei FX, Qi XP, et al. Efficacy and safety of endoscopic intralesional triamcinolone injection for benign esophageal strictures. Gastroenterol Res Pract 2018;2018:7619298.

36. Dasari CS, Jegadeesan R, Patel HK, et al. Intralesional steroids and endoscopic dilation for anastomotic strictures after esophagectomy: systematic review and meta-analysis. Endoscopy 2020;52:721-726.

37. Hanaoka N, Ishihara R, Motoori M, et al. Endoscopic balloon dilation followed by intralesional steroid injection for anastomotic strictures after esophagectomy: a randomized controlled trial. Am J Gastroenterol 2018;113:1468-1474.

38. Spaander MC, Baron TH, Siersema PD, et al. Esophageal stenting for benign and malignant disease: European Society of Gastrointestinal Endoscopy (ESGE) Clinical Guideline. Endoscopy 2016;48:939-948.

39. Berger M, Ure B, Lacher M. Mitomycin C in the therapy of recurrent esophageal strictures: hype or hope? Eur J Pediatr Surg 2012;22:109-116.

40. Rashed YK, El-Guindi M. Endoscopic postdilatation application of Mitomycin C in children with resistant esophageal strictures. Korean J Pediatrics 2019;62:395-399.

41. Bartel MJ, Seeger K, Jeffers K, et al. Topical mitomycin C application in the treatment of refractory benign esophageal strictures in adults and comprehensive literature review. Dig Liver Dis 2016;48:10581065.

42. Gusmon-Oliveira CC, Kuboki YM, de Paulo GA, et al. Endoscopic injection of mitomycin $\mathrm{C}$ for the treatment of pharyngoesophageal stenosis refractory to endoscopic treatment with dilatation in patients treated for head and neck cancer. Gastroenterol Res Pract 2018:5428157.

43. Wu Y, Schomisch SJ, Cipriano C, et al. Preliminary results of antiscarring therapy in the prevention of postendoscopic esophageal mucosectomy strictures. Surg Endosc 2014;28:447-455.

44. Rahbar R, Jones DT, Nuss RC, et al. The role of mitomycin in the prevention and treatment of scar formation in the pediatric aerodigestive tract: friend or foe? Arch Otolaryngol Head Neck Surg 2002;128:401-406.
45. Gillespie MB, Day TA, Sharma AK, et al. Role of mitomycin in upper digestive tract stricture. Head Neck 2007;29:12-17.

46. El-Asmar KM, Hassan MA, Abdelkader HM, et al. Topical mitomycin $\mathrm{C}$ application is effective in management of localized caustic esophageal stricture: a double-blinded, randomized, placebo-controlled trial. J Pediatr Surg 2013;48:1621-1627.

47. Fernandes J, Libanio D, Giestas S, et al. Esophageal anastomotic stricturotomy: electroincision therapy with a needle knife. GE Port J Gastroenterol 2019;26:137-138.

48. Chiang AL, Abidi WM, Thompson CC. Treatment of recurrent esophageal stricture with an insulated-tip electrosurgical knife and mitomycin C. Endoscopy 2017;49:E68-E69.

49. Hordijk ML, Siersema PD, Tilanus HW, et al. Electrocautery therapy for refractory anastomotic strictures of the esophagus. Gastrointest Endosc 2006;63:157-163.

50. Lee TH, Lee SH, Park JY, et al. Primary incisional therapy with a modified method for patients with benign anastomotic esophageal stricture. Gastrointest Endosc 2009;69:1029-1033.

51. Ham YH, Kim GH. Plastic and biodegradable stents for complex and refractory benign esophageal strictures. Clin Endosc 2014;47:295-300.

52. Baron TH. Expandable metal stents for the treatment of cancerous obstruction of the gastrointestinal tract. $N$ Engl J Med 2001;344:1681-1687.

53. Sharma P, Kozarek R, Practice Parameters Committee of American College of G. Role of esophageal stents in benign and malignant diseases. Am J Gastroenterol 2010;105:258-273; quiz 274.

54. Bektas H, Gurbulak B, Duzkoylu Y, et al. Clinical outcomes of upper gastrointestinal stents and review of current literature. JSLS 2017;21:e2017.00058.

55. Wang MQ, Sze DY, Wang ZP, et al. Delayed complications after esophageal stent placement for treatment of malignant esophageal obstructions and esophagorespiratory fistulas. J Vasc Interv Radiol 2001;12:465-474.

56. Homann N, Noftz MR, Klingenberg-Noftz RD, et al. Delayed complications after placement of self-expanding stents in malignant esophageal obstruction: treatment strategies and survival rate. Dig Dis Sci 2008;53:334-340.

57. Adler DG. Lumen-apposing metal stents for the treatment of refractory benign esophageal strictures. Am J Gastroenterol 2017;112:516-517.

58. Hallac A, Srikureja W, Liu E, et al. Economical effect of lumen apposing metal stents for treating benign foregut strictures. World J Gastrointest Endosc 2018;10:294-300.

59. Granata A, Amata M, Ligresti D, et al. Novel lumen-apposing stent to treat benign esophageal stricture. Endoscopy 2017;49:E273-E274.

60. Irani S, Jalaj S, Ross A, et al. Use of a lumen-apposing metal stent to treat GI strictures (with videos). Gastrointest Endosc 2017;85:1285-1289.

61. Gangloff A, Lecleire S, Di Fiore A, et al. Fully versus partially covered self-expandable metal stents in benign esophageal strictures. Dis Esophagus 2015;28:678-683.

62. Fuccio L, Hassan C, Frazzoni L, et al. Clinical outcomes following stent placement in refractory benign esophageal stricture: a systematic review and meta-analysis. Endoscopy 2016;48:141-148.

63. Lanza FL, Graham DY. Bougienage is effective therapy for most benign esophageal strictures. JAMA 1978;240:844-847.

64. Dzeletovic I, Fleischer DE, Crowell MD, et al. Self-dilation as a treatment for resistant, benign esophageal strictures. Dig Dis Sci 2013;58:3218-3223.

65. van Halsema EE, t Hoen CA, de Koning PS, et al. Self-dilation for therapy-resistant benign esophageal strictures: towards a systematic approach. Surg Endosc 2018;32:3200-3207.

66. Qin Y, Sunjaya DB, Myburgh S, et al. Outcomes of oesophageal selfdilation for patients with refractory benign oesophageal strictures. 
Aliment Pharmacol Ther 2018;48:87-94.

67. Mormando J, Barbetta A, Molena D. Esophagectomy for benign disease. J Thorac Dis 2018;10:2026-2033.

68. Schubert D, Kuhn R, Lippert H, et al. Endoscopic treatment of benign gastrointestinal anastomotic strictures using argon plasma coagulation in combination with diathermy. Surg Endosc 2003;17:1579-1582.

69. Simmons DT, Baron TH. Electroincision of refractory esophagogastric anastomotic strictures. Dis Esophagus 2006; 19:410-414.

70. Hordijk ML, van Hooft JE, Hansen BE, et al. A randomized comparison of electrocautery incision with Savary bougienage for relief of anastomotic gastroesophageal strictures. Gastrointest Endosc 2009;70:849-855.

71. Muto M, Ezoe Y, Yano T, et al. Usefulness of endoscopic radial incision and cutting method for refractory esophagogastric anastomotic stricture (with video). Gastrointest Endosc 2012;75:965-972.

72. Tan Y, Liu D. Endoscopic incision for the treatment of refractory esophageal anastomotic strictures: outcomes of 13 cases with a minimum follow-up of 12 months. Rev Esp Enferm Dig 2016;108:196-200.

73. Pross M, Manger T, Lippert H. Combination of diathermy and argon plasma coagulation in treatment of cicatricial esophageal stenoses. Zentralbl Chir 1998;123:1145-1147.

74. Hagiwara A, Togawa T, Yamasaki J, et al. Endoscopic incision and balloon dilatation for cicatricial anastomotic strictures. Hepatogastroenterology 1999;46:997-999.

75. Brandimarte G, Tursi A. Endoscopic treatment of benign anastomotic esophageal stenosis with electrocautery. Endoscopy 2002;34:399-401.

76. DiSario JA, Pedersen PJ, Bichiş-Canoutas C, et al. Incision of recurrent distal esophageal (Schatzki) ring after dilation. Gastrointest Endosc 2002;56:244-248.

77. Burdick JS, Venu RP, Hogan WJ. Cutting the defiant lower esophageal ring. Gastrointest Endosc 1993;39:616-619.

78. Song HY, Jung HY, Park SI, et al. Covered retrievable expandable nitinol stents in patients with benign esophageal strictures: initial experience. Radiology 2000;217:551-557.

79. Kim JH, Song HY, Choi EK, et al. Temporary metallic stent placement in the treatment of refractory benign esophageal strictures: results and factors associated with outcome in 55 patients. Eur Radiol 2009;19:384-390.

80. Bakken JC, Wong Kee Song LM, de Groen PC, et al. Use of a fully covered self-expandable metal stent for the treatment of benign esophageal diseases. Gastrointest Endosc 2010;72:712-720.

81. Eloubeidi MA, Talreja JP, Lopes TL, et al. Success and complications associated with placement of fully covered removable selfexpandable metal stents for benign esophageal diseases (with videos). Gastrointest Endosc 2011;73:673-681.

82. Hirdes MM, Siersema PD, Vleggaar FP. A new fully covered metal stent for the treatment of benign and malignant dysphagia: a prospective follow-up study. Gastrointest Endosc 2012;75:712-718

83. Liu J, Hu Y, Cui C, et al. Removable, fully covered, self-expandable metal stents for the treatment of refractory benign esophagogastric anastomotic strictures. Dysphagia 2012;27:260-264.

84. Canena JM, Liberato MJ, Rio-Tinto RA, et al. A comparison of the temporary placement of 3 different self-expanding stents for the treatment of refractory benign esophageal strictures: a prospective multicentre study. BMC Gastroenterol 2012;12:70.

85. Chaput U, Heresbach D, Audureau E, et al. Comparison of a standard fully covered stent with a super-thick silicone-covered stent for the treatment of refractory esophageal benign strictures: A prospective multicenter study. United European Gastroenterol J 2013;1:93-102.

86. Dan DT, Gannavarapu B, Lee JG, et al. Removable esophageal stents have poor efficacy for the treatment of refractory benign esophageal strictures (RBES). Dis Esophagus 2014;27:511-517.

87. Repici A, Conio M, De Angelis C, et al. Temporary placement of an expandable polyester silicone-covered stent for treatment of refractory benign esophageal strictures. Gastrointest Endosc 2004;60:513-519.

88. Evrard S, Le Moine O, Lazaraki G, et al. Self-expanding plastic stents for benign esophageal lesions. Gastrointest Endosc 2004;60:894-900.

89. Karbowski M, Schembre D, Kozarek R, et al. Polyflex selfexpanding, removable plastic stents: assessment of treatment efficacy and safety in a variety of benign and malignant conditions of the esophagus. Surg Endosc 2008;22:1326-1333.

90. Dua KS, Vleggaar FP, Santharam R, et al. Removable self-expanding plastic esophageal stent as a continuous, non-permanent dilator in treating refractory benign esophageal strictures: a prospective twocenter study. Am J Gastroenterol 2008;103:2988-2994.

91. Martin RC, Woodall C, Duvall R, et al. The use of self-expanding silicone stents in esophagectomy strictures: less cost and more efficiency. Ann Thorac Surg 2008;86:436-440.

92. Oh YS, Kochman ML, Ahmad NA, et al. Clinical outcomes after self-expanding plastic stent placement for refractory benign esophageal strictures. Dig Dis Sci 2010;55:1344-1348.

93. van Boeckel PG, Vleggaar FP, Siersema PD. A comparison of temporary self-expanding plastic and biodegradable stents for refractory benign esophageal strictures. Clin Gastroenterol Hepatol 2011;9:653-659.

94. Repici A, Vleggaar FP, Hassan C, et al. Efficacy and safety of biodegradable stents for refractory benign esophageal strictures: the BEST (Biodegradable Esophageal Stent) study. Gastrointest Endosc 2010;72:927-934.

95. Hirdes MM, Siersema PD, van Boeckel PG, et al. Single and sequential biodegradable stent placement for refractory benign esophageal strictures: a prospective follow-up study. Endoscopy 2012;44:649-654. 